\title{
COMB-TYPE FLUORINE-CONTAINING POLYMER ELECTROLYTE MEMBRANES
}

\author{
FLUOR VSEBUJOČE POLIMERNE ELEKTROLITNE MEMBRANE \\ V OBLIKI SATOVJA
}

\author{
Omar Mukbaniani ${ }^{1,2}$, Witold Brostow ${ }^{3}$, Jimsher Aneli ${ }^{1,2}$, Eliza Markarashvilii,2, \\ Tamara Tatrishvili ${ }^{1,2}$ \\ ${ }^{1}$ Faculty of Exact and Natural Sciences, Department of Macromolecular Chemistry, Ivane Javakhishvili Tbilisi State University, Ilia \\ Chavchavadze Ave. 3, Tbilisi 0179, Georgia \\ ${ }^{2}$ Institute of Macromolecular Chemistry and Polymeric Materials, Ivane Javakhishvili Tbilisi State University, Ilia Chavchavadze Ave. 3 , \\ Tbilisi 0179, Georgia \\ ${ }^{3}$ Laboratory of Advanced Polymers \& Optimized Materials (LAPOM), Department of Materials Science and Engineering and Department of \\ Physics, University of North Texas, 3940 North Elm Street, Denton, TX 76207, USA
}

Prejem rokopisa - received: 2019-04-29; sprejem za objavo - accepted for publication: 2019-09-30

doi:10.17222/mit.2019.091

Using a hydrosilylation reaction of 2.4.6.8-tetrahydro-2.4.6.8-tetramethylcyclotetrasiloxane $\left(\mathrm{D}_{4}{ }^{\mathrm{H}}\right)$ with 2.2 .3 .3 -tetrafluoropropyl acrylate and vinyltriethoxysilane at a 1:3:1 ratio of the initial compounds in the presence of platinum catalysts, a new $\mathrm{D}_{4}{ }^{\mathrm{R}}{ }^{\prime}$ type fluorine-containing methylorganocyclosiloxane was obtained. Via a ring-opening co-polymerization reaction of $\mathrm{D}_{4}{ }^{\mathrm{R}, \mathrm{R}}$ type methylorganocyclotetrasiloxane in a solution, in the presence of catalysts, anhydrous powder-like potassium hydroxide, or tetramethylammonium fluoride, new comb-type siloxane matrices with pendant ethyl tetrafluopropionate side groups and cross-linkable triethoxysilane moieties were obtained. The synthesized comb-type polymers were analysed with FTIR, ${ }^{1} \mathrm{H}$, ${ }^{13} \mathrm{C}$, and ${ }^{29} \mathrm{Si}$ NMR spectroscopy as well as the DSC and GPC methods. Sol-gel reactions of polymers doped with lithium trifluoromethanesulfonate (triflate) and lithium bis(trifluoromethanesulfonyl)imide were studied and solid polymer electrolyte membranes were obtained. The ion conductivity of the membranes was determined via electrical impedance spectroscopy.

Keywords: hydrosilylation, polymerization, SEM, sol-gel, thermogravimetric analysis

Avtorji so izdelali novi $\mathrm{D}_{4}{ }^{\mathrm{RR}}$ ' tip fluor vsebujočega metilorganociklosiloksana s hidrosililacijsko reakcijo 2.4.6.8-tetrahidro-2.4.6.8-tetrametilciklotetrasiloksana $\left(\mathrm{D}_{4}^{\mathrm{H}}\right) \mathrm{z}$ 2.2.3.3-tetrafluoropropil akrilatom in viniltrietoksilanom pri razmerju 1:3:1 začetnih spojin $v$ prisotnosti Pt katalizatorja. Preko odprto-obročne kopolimerizacijske reakcije $D_{4}{ }^{R, R}{ }^{\prime}$ so izdelali novo siloksansko matrico, v obliki satovja, s pripeto stransko tetrafluopropionatno skupino in prečno zamreženo trietoksisilansko skupino v raztopini metilorganociklotetrasiloksana, v prisotnosti katalizatorjev, anhidridnega prahu $\mathrm{KOH}$ ali tetrametilamonijevega fluorida. Sintetizirani polimer v obliki satovja so analizirali s FTIR, ${ }^{1} \mathrm{H},{ }^{13} \mathrm{C}$, in ${ }^{29} \mathrm{Si}$ NMR spektroskopijami ter DSC- in GPC-metodama. Studirali so sol-gel reakcije polimerov, dopiranih z litijevim trifluorometanesulfonatom (triflat) in litijevim bi(trifluorometanosulfonil) imidom in so dobili trdne polimerne elektrolitne membrane. Ionsko prevodnost membran so določili s pomočjo elektro-impedančne spektroskopije.

Ključne besede: hidrosilanizacija, polimerizacija, SEM, sol-gel, termogravimetrična analiza

\section{INTRODUCTION}

The development of new and more efficient methods of energy storage and conversion is increasing in importance. This includes the efficient storage of electricity, leading to the development of batteries and other energy-storage devices with a high energy density, low energy losses during an operation, a low cost and long lifetime. ${ }^{1-4}$ The promotion of the anion-cation dissociation is desirable because it leads to an enhancement of ionic conductivity via an increase in the free-ion concentration. Following the realisation that the ionic conductivity of polymer electrolytes is enhanced in the elastomeric amorphous phase by the segmental motion of the polymer chains, significant research was undertaken to develop an amorphous polymer structure with a highly flexible backbone.

*Corresponding author's e-mail:

omar.mukbaniani@tsu.ge (Omar Mukbaniani)
Among the polyphosphazenes, polyacrylate and inorganic polymers, polysiloxanes are particularly promising because they can have a wide variety of substituents bound to silicones in the backbone of the alternating silicon and oxygen atoms. Polysiloxanes are superior to polyphosphazenes because of their backbone flexibility, high chemical- and thermal-oxidation stability, easy processing as well as a low cost and low toxicity. ${ }^{2,5-7}$

It is well known that polysiloxanes are characterized with very low glass temperatures such as $T_{\mathrm{g}}=-123{ }^{\circ} \mathrm{C}$ for polydimethylsiloxane, a very high free volume and high segmental mobility and presently the best matrix for an Li-ion transportation. The high solubility of the corresponding salt in the polymer is another factor for the achievement of high ion conductivity. This condition is created with an introduction to the polymer-electrolyte main chain or side group of such a "host" donor group, like the ester oxygen imide group, halogen, and especially, fluorine groups. The formation of grid-like 
structures increases the mechanical properties of polymer electrolytes. ${ }^{5,8-10}$

Among organosilicon compounds, the comb-type polymers with donor fragments at silicon atoms are of interest. Such polymers are mainly obtained via hydrolytic polycondensation reaction donor groups containing diorganodichlorosilanes, or with modification reactions of industrially available polymethylhydrosiloxane (PMHS), via a hydrosilylation reaction of polymethylhydrosiloxane with allyl-, vinyl- or unsaturated bonds containing compounds in the presence of platinum catalysts (Pt/C, platinum hydrochloric acid, Karstedt's catalyst), ${ }^{10}$ or else using dehydrocoupling reactions of polymethylhydrosiloxane with hydroxyl- and donor groups containing compounds in the presence of catalysts.

One of the ways of the synthesis of comb-type polyorganosiloxanes is the hydrosilylation reaction of 2.4.6.8-tetramethyl-2.4.6.8-tetrahydrocyclotetrasiloxane (methylcyclotri-, -pentasiloxanes) with allyl or vinyl containing compounds in the presence of platinum catalysts, followed by polymerization or copolymerization reactions of the obtained organocyclosiloxanes in the presence of terminating (regulating) agent hexamethyldisiloxane or without it - in the presence of nucleophilic catalysts. Thus, polyorganosiloxanes with a regular arrangement of the side donor groups can be obtained. ${ }^{11,12}$

As expected, the properties of the comb-type organosilicon polymers depend on the structure of macromolecular chains and on the nature of the organic groups surrounding the silicon atom. ${ }^{8}$ In the comb-type copolymers, there are organic substituent groups of different sizes and types bonded to the methylsiloxane hydrophobic matrix. A wide range of variations of these substituent groups is possible. Some organosilicon copolymers contain donor groups and exhibit complexation properties. ${ }^{9,10}$

A variety of organic donor groups can be bound to silicon, including fluorine host groups in the side chain of a siloxane matrix, which provides a possibility to vary the ion-conducting properties of polymer electrolyte membranes.

The aims of our work were the synthesis of $D_{4}{ }^{R, R^{\prime}}$ type methylcyclotetrasiloxane with 2,2,3,3-tetrafluoropropyl propionate side groups and ethylsilyltriethoxy groups (as cross-linking moieties) on silicon; the determination of their structure with the FTIR and NMR spectroscopy; an investigation of co-polymerization reactions of $\mathrm{D}_{4}{ }^{\mathrm{R}, \mathrm{R}^{\prime}}$ with terminating agent hexamethyldisiloxane and the obtaining of comb-type polymers; sol-gel reactions of comb-type polymers for obtaining new solid polymer electrolyte membranes on the basis of lithium salts: lithium trifluoromethanesulfonate and lithium bis(trifluoromethanesulfonyl)imide; and a study of their electrical and other physical properties.

\section{EXPERIMENTAL PART}

\subsection{Materials}

2.4.6.8-tetrahydro-2.4.6.8-tetramethylcyclotetrasiloxane $\left(\mathrm{D}_{4}{ }^{\mathrm{H}}\right)$, platinum hydrochloric acid, Karstedt's catalyst $\left(\mathrm{Pt}_{2}\left[\left(\mathrm{VinSiMe}_{2}\right)_{2} \mathrm{O}\right]_{3}\right)$ or platinum (0)-1,3divinyl-1,1,3,3-tetramethyldi-siloxane complex (2-\% solution in xylene) and platinum hydrochloric acid (Aldrich), Pt/C (10\%), were used as received. Lithium trifluoromethanesulfonate (triflate) and lithium bis(trifluoromethanelsulfonyl)imide were also purchased from Aldrich. Toluene was dried over and distilled from sodium under an atmosphere of dry nitrogen.

Tetrahydrofuran (THF) was dried over and distilled from a $\mathrm{K}-\mathrm{Na}$ alloy under an atmosphere of dry nitrogen. $0.1-\mathrm{M}$ solution of the platinum hydrochloric acid in THF was prepared and kept under nitrogen at a low temperature.

\subsection{Characterization}

FTIR spectra were recorded on a Nicolet Nexus 470 machine with an MCTB detector. ${ }^{1} \mathrm{H},{ }^{13} \mathrm{C}$ NMR and ${ }^{29} \mathrm{Si}$ NMR spectra were recorded on a Varian Mercury 300VX NMR spectrometer, using DMSO (dimethyl sulfoxide, $\left.\left(\mathrm{CH}_{3}\right)_{2} \mathrm{SO}\right)$ and $\mathrm{CCl}_{4}$ as the solvent and an internal standard, respectively. A differential-scanning-calorimetric (DSC) investigation was performed on a Net-zsch DSC 200 F3 Maia apparatus. Glass-transition temperatures $(\mathrm{Tg})$ were read from endothermic DSC traces, which were approximated to be midpoints between the extrapolated tangents to the baselines above and below the glass-transition region. The heating and cooling scanning rates were $10 \mathrm{~K} / \mathrm{min}$. Scanning electron microscopy and X-ray energy dispersion microscopy were performed on Hitachi TM3030 Plus devices.

Gel-permeation chromatography (GPC) was carried out with a Waters Model 6000A chromatograph with an $\mathrm{R} 401$ differential refraction meter detector. The column set comprised $10^{3}$ and $10^{4} \AA$ ultrastyragel columns. The sample concentration was approximately $3 \%$ by weight in toluene; the typical injection volume for the siloxane was $5 \mu \mathrm{L}$ and the flow rate was about $1.0 \mathrm{~mL} / \mathrm{min}$. Standardization of the GPC was accomplished with the use of styrene or polydimethylsiloxane standards with the known molecular weight. Determination of $\equiv \mathrm{Si}-\mathrm{H}$ content was calculated according to the method described in the reference ${ }^{13}$.

\subsection{Hydrosilylation reaction of $\mathrm{D}_{4}{ }^{\mathrm{H}}$ with 2.2.3.3-tetra- fluoropropyl acrylate and vinyltriethoxysilane}

$\mathrm{D}_{4}{ }^{\mathrm{H}}$ (1.200 g, 0.00499 mole) was transferred into a 100-ml flask under nitrogen using the standard Schlenk technique. High vacuum was applied to the flask for half an hour before the addition of 2.2.3.3-tetrafluoropropyl acrylate $(2.784 \mathrm{~g}, 0.01497$ mole). The mixture was then dissolved in $7 \mathrm{~mL}$ of toluene; a $0.1-\mathrm{M}$ solution of 
platinum hydrochloric acid in tetrahydrofuran (from 5 to $9 \cdot 10^{-5} \mathrm{~g}$ per $1.0 \mathrm{~g}$ of the starting substance) was introduced. The homogeneous mixture was degassed and placed into an oil bath, which was previously set to $50{ }^{\circ} \mathrm{C}$ and the reaction continued at $50{ }^{\circ} \mathrm{C}$. After $1 \mathrm{~h}, 0.949 \mathrm{~g}$ (0.00499 mole) of vinyltriethoxysilane in $1 \mathrm{~mL}$ of toluene was added. The reaction was controlled with a decrease in the intensity of active $\equiv \mathrm{Si}-\mathrm{H}$ groups. Then $0.1 \%$ of activated carbon was added and refluxed for $12 \mathrm{~h}$ for a deactivation of the catalysts.

All volatile products were removed with rotary evaporation and the compound was precipitated at least three times into pentane to remove side products. Finally, all volatiles were removed under vacuum and further evacuated under a high vacuum for $24 \mathrm{~h}$ to isolate $4.58 \mathrm{~g}$ $(93.0 \%)$ of colourless viscous compound I 2.4.6.8-tetramethyl-2.4.6-tri(2.2.3.3-tetrafluoropropyl propionate)-8-ethyltriethoxysilane cyclotetrasiloxane $\left(\mathrm{D}_{4}{ }^{\mathrm{R}, \mathrm{R}^{\prime}}\right)$. For $\mathrm{D}_{4}{ }^{\mathrm{R}, \mathrm{R}^{\prime}}$ founded $\mathrm{n}_{\mathrm{D}}{ }^{20}=1.3977 ; \mathrm{d}_{4}{ }^{20}=1.3772$; $\mathrm{M}_{\mathrm{RD}}=183.3 ; \mathrm{M}=955$ (the ebullioscopy method). Calculated: $\mathrm{M}_{\mathrm{RD}}=183.3 ; \mathrm{M}=988$.

FTIR spectra $\left(\mathrm{KBr}, v\right.$-values in $\left.\mathrm{cm}^{-1}\right)$ provided the following results: no $\equiv \mathrm{Si}-\mathrm{H}$ absorption at $2169 ; 1080$ (三SiOSi $\equiv), 958,1128$ (C-F), 1171 (CO-O), 1270 (Si-C), $1762(\mathrm{C}=\mathrm{O})$ and 2800-3100 (C-H). ${ }^{1} \mathrm{H}$ NMR (d-DMSO, $\left.\mathrm{CCl}_{4}\right),(\mathrm{mg} / \mathrm{L}) \delta$ values: 0.14 (Si-Me), 0.56, $1.2\left(\mathrm{~m}, \mathrm{Si}-\mathrm{CH}_{2}-\right.$ anti-Markovnikov addition), 0.9, 1.6 (m, =CH- $\mathrm{CH}_{3}$ Markovnikov addition); 0.9, 1.60 (m, $\left.=\mathrm{CH}-\underline{\mathrm{CH}}_{3}\right), 1.64,2,6\left(\mathrm{~m},=\underline{\mathrm{CH}}-\mathrm{CH}_{3}\right), 2.4\left(\mathrm{~m}, \mathrm{CH}_{2}-\mathrm{O}\right)$ overlaps with the signals of methine groups, $3.8(\mathrm{~m}$, $\left.\mathrm{Si}-\mathrm{O}-\mathrm{C}_{2}{ }_{2}\right), 4.5\left(\mathrm{t}, \mathrm{C}_{2}-\mathrm{CF}_{2}\right), 5.95-5.61\left(\mathrm{t}, \mathrm{CF}_{2} \underline{\mathrm{H}}\right) .{ }^{13} \mathrm{C}$ NMR (d-DMSO, $\left.\mathrm{CCl}_{4}\right),(\mathrm{mg} / \mathrm{L}):-1.92\left(\mathrm{Si}-\mathrm{CH}_{3}\right), 1.49$, $7.9,8.8,18.2,26.6,27.1,58.4107,107.8$ and 173 correspond to the carbon atoms in groups $\mathrm{OCH}_{2}-\mathrm{CH}_{3}$, $=\mathrm{CH}-\underline{\mathrm{CH}_{3}}, \quad=\underline{\mathrm{CH}}-\mathrm{CH}_{3}, \quad \equiv \mathrm{SiCH}_{2} \mathrm{CH}_{2}-, \quad-\underline{\mathrm{CH}_{2}} \mathrm{CO}-$, $\mathrm{O}^{-} \mathrm{H}_{2} \mathrm{CH}_{3},-\mathrm{CO}-\underline{\mathrm{CH}}_{2}-\mathrm{CF}_{2}-,-\underline{\mathrm{CF}}_{2}-,-\underline{\mathrm{CHF}}_{2}$ and $\underline{\mathrm{C}}=\mathrm{O}$. ${ }^{29} \mathrm{Si} \quad \mathrm{NMR} \quad(\mathrm{mg} / \mathrm{L}):-18.6 \quad-20.4 . \quad-46.0 \quad-57.0$, $-665.0 . .^{12,14,15}$

The hydrosilylation reactions in the presence of other catalysts were carried out in accordance with the same method.

\subsection{Ring-opening co-polymerization reaction of $D_{4}{ }^{R, R}$, with regulated agent hexamethyldisiloxane}

$1.137 \mathrm{~g}$ (1.150 mmole) of the $\mathrm{D}_{4}{ }^{\mathrm{R}, \mathrm{R}^{\prime}}$ compound and $0.0386 \mathrm{~g}$ ( $0.223 \mathrm{mmole})$ of hexamethyldisiloxane were transferred into a 50-ml flask under nitrogen. A high vacuum was applied to the flask for half an hour. Then the compound was dissolved in 1.8-ml dry toluene and $0.01 \%$ of the total mass powder form potassium hydroxide was added. The mixture was degassed, placed in an oil bath that was previously set to $60{ }^{\circ} \mathrm{C}$ and polymerized under nitrogen for $25 \mathrm{~h}$. Then $7 \mathrm{~mL}$ of toluene were added to the reaction mixture and the product was washed with water. The crude product was stirred with $\mathrm{MgSO}_{4}$ for $6 \mathrm{~h}$, filtered and evaporated; the polymer was precipitated at least three times into pentane to remove side products. Finally, all volatiles were removed under a vacuum up to a constant mass, after that $1.0 \mathrm{~g} \mathrm{(85 \% )} \mathrm{of}$ colourless viscous polymer (II) was isolated. For oligomer II founded $\eta_{\mathrm{sp}}=0.19 ; T_{\mathrm{g}}=-73--76^{\circ} \mathrm{C} ; \mathrm{M}_{\mathrm{n}}=$ $3.775 \cdot 10^{3} ; \mathrm{M}_{\omega}=4.137 \cdot 10^{3}(\mathrm{D}=1.1)$.

FTIR $\left(\mathrm{KBr}, \quad \mathrm{cm}^{-1}\right), \quad v_{\text {as }}: 786\left(\equiv \mathrm{Si}-\mathrm{CH}_{3}\right), \quad 1080$ (三SiOSi $\equiv), 958,1128$ (C-F), $1171 \quad(\mathrm{CO}-\mathrm{O}), 1270$ (Si-C), $1762(\mathrm{C}=\mathrm{O})$ and 2800-3100 (C-H). ${ }^{1} \mathrm{H}$ NMR (d-DMSO, CCl4), (mg/L) $\delta: 0.14$ (Si-Me), 0.56, 1.2 (m, $\equiv \mathrm{Si}-\mathrm{CH}_{2}-$ anti-Markovnikov addition), 0.9, $1.6(\mathrm{~m}$, $=\mathrm{CH}-\mathrm{CH}_{3}$ Markovnikov addition); 0.9, 1.60 (m, $\left.=\mathrm{CH}-\underline{\mathrm{CH}}_{3}\right), 1.64,2,6\left(\mathrm{~m},=\underline{\mathrm{CH}}-\mathrm{CH}_{3}\right), 2.4\left(\mathrm{~m}, \mathrm{CH}_{2}-\mathrm{O}\right)$ overlaps with the signals of methine groups, $3.8(\mathrm{~m}$, $\left.\mathrm{Si}-\mathrm{O}-\mathrm{C}_{2}\right), 4.5\left(\mathrm{t}, \mathrm{C}_{2}-\mathrm{CF}_{2}\right), 5.95-5.61\left(\mathrm{t}, \mathrm{CF}_{2} \underline{\mathrm{H}}\right) .{ }^{13} \mathrm{C}$ NMR (d-DMSO, CCl4), (mg/L) $\delta:-1.92\left(\mathrm{Si}_{-} \mathrm{CH}_{3}\right), 1.49$, 7.9, 8.8, 18.2, 26.6, 27.1, $58.4107,107.8$ and 173 correspond to the carbon atoms in groups $-\mathrm{OCH}_{2}-\mathrm{CH}_{3}$, $=\mathrm{CH}-\underline{\mathrm{CH}_{3}}, \quad=\underline{\mathrm{C}} \mathrm{H}-\mathrm{CH}_{3}, \quad \equiv \mathrm{SiCH}_{2} \mathrm{CH}_{2}-, \quad-\underline{\mathrm{C}} \mathrm{H}_{2} \mathrm{CO}-$, $\mathrm{O}_{\underline{C}} \mathrm{H}_{2} \mathrm{CH}_{3},-\mathrm{CO}-\mathrm{CH}_{2}-\mathrm{CF}_{2}-,-\underline{\mathrm{CF}}_{2}-,-\underline{\mathrm{C}} \mathrm{HF}_{2}$ and $\underline{\mathrm{C}}=\mathrm{O}$. ${ }^{29} \mathrm{Si}$ NMR (mg/L): -18.6-20.4. $-46.0 \quad-\quad-57.0$, $-665.0 .^{12,14,15}$

The ring-opening polymerization reaction of compound I at various temperatures was carried out in the same manner.

\subsection{General procedure for the preparation of cross- linked polymer electrolytes}

During a typical preparation, $0.75 \mathrm{~g}$ of polymer II was dissolved in $4 \mathrm{~mL}$ of dry THF and thoroughly mixed for half an hour before an addition of a catalytic amount of acid (one drop of $0.1 \mathrm{~N} \mathrm{HCl}$ solution in ethyl alcohol) to initiate the cross-linking process. After stirring for another $3 \mathrm{~h}$, the required amount of lithium triflate from the previously prepared stock solution in THF was added to the mixture and the stirring continued for $1 \mathrm{~h}$ more. The mixture was then poured onto a Teflon mould with a diameter of $4 \mathrm{~cm}$ and the solvent was allowed to evaporate slowly overnight. Finally, the membrane was dried in an oven at $70{ }^{\circ} \mathrm{C}$ for $3 \mathrm{~d}$ and at $100{ }^{\circ} \mathrm{C}$ for $1 \mathrm{~h}$. Homogeneous and transparent films with the average thickness of $200 \mu \mathrm{m}$ were thus obtained. These films are insoluble in typical solvents and only swell in THF. The preparation of solid polymer electrolyte membranes with lithium bis(trifluoromethanesulfonyl)imide was carried out in the same manner.

\subsection{AC impedance measurements}

The total ionic conductivity of the samples was determined by placing an electrolyte disk between two 10 -mm-diameter brass electrodes. The electrode/electrolyte assembly was secured in a suitable constantvolume support, which allowed highly reproducible measurements of conductivity to be performed between repeated heating/cooling cycles. The cell support was located in an oven and the sample temperature was measured by a thermocouple positioned close to the ele- 
ctrolyte disk. The bulk conductivities of the electrolytes were determined during a heating cycle using the impedance technique (a BM 507 - TESLA impedance meter for frequencies of $50 \mathrm{~Hz}-500 \mathrm{kHz}$ ) over a temperature range of $20-100{ }^{\circ} \mathrm{C}$.

\section{RESULTS}

\subsection{Hydrosilylation reaction of $\mathrm{D}_{4}{ }^{\mathrm{H}}$ with 2.2.3.3-tetra- fluoropropyl acrylate and vinyltriethoxysilane}

The synthesis of $\mathrm{D}_{4}{ }^{\mathrm{R}, \mathrm{R}^{\prime}}$ type methylorganocyclotetrasiloxane with 2.2.3.3-tetrafluoropropyl propionate and ethyltriethoxysilylated groups on silicon was performed via a hydrosilylation reaction of 2.4.6.8-tetrahydro-2.4.6.8-tetramethylcyclotetrasiloxane $\left(\mathrm{D}_{4}{ }^{\mathrm{H}}\right)$ with 2.2.3.3-tetrafluoropropyl acrylate and vinyltriethoxysilane in the presence of platinum catalysts (platinum hydrochloric acid, Karstedt's catalysts) and Pt/C (10\%) at $50{ }^{\circ} \mathrm{C}$ in the melt condition as well as in a toluene solution. It was established that the hydrosilylation reaction of $\mathrm{D}_{4}{ }^{\mathrm{H}}$ with 2.2.3.3-tetrafluoropropyl acrylate and vinyltriethoxysilane proceeds vigorously during the first 3-7 $\mathrm{min}$. The reaction was controlled by a decrease in the intensity of active $\equiv \mathrm{Si}-\mathrm{H}$ groups in the $2160-2170$ $\mathrm{cm}^{-1}$ region. From ${ }^{16}$ it is known that a hydrosilylation reaction of 2.4.6.8-etrahydro-2.4.6.8-etramethylcyclotetrasiloxane $\left(\mathrm{D}_{4}{ }^{\mathrm{H}}\right)$ with allyl butyrate and vinyltriethoxysilane in the melt condition proceeds vigorously, changing the direction of the hydride addition and partially substituted hydroxyl containing methylcyclotetrasiloxane is obtained.

To mitigate side reactions and obtain fully substituted cyclotetrasiloxanes $\left(\mathrm{D}_{4}^{\mathrm{R}, \mathrm{R}^{\prime}}\right)$, we investigated hydrosilylation reactions of $\mathrm{D}_{4}{ }^{\mathrm{H}}$ with 2.2 .3 .3-tetrafluoropropyl acrylate and vinyltriethoxysilane at a 1:3:1 ratio of the initial compounds and studied the reactions in a dry diluted toluene solution at various temperatures: (30, 40 and 50) ${ }^{\circ} \mathrm{C}$. During the hydride-addition reactions, the changes in active $\equiv \mathrm{Si}-\mathrm{H}$ bonds' concentrations with time were observed, and the decrease in the active $\mathrm{Si}-\mathrm{H}$ bond concentration in the hydrosilylation reaction was controlled by a well-known method. ${ }^{13}$

We found that the activity of the catalysts during the hydrosilylation reactions of $\mathrm{D}_{4}{ }^{\mathrm{H}}$ with 2.2.3.3-tetrafluoropropyl acrylate and vinyltriethoxysilane decreases in the following order: Karstedt's catalyst $\approx \mathrm{H}_{2} \mathrm{PtCl}_{6}>$ $\mathrm{Pt} / \mathrm{C}$.

The reaction proceeds according to Scheme 1.

Therefore, the obtained organocyclotetrasiloxane I is a transparent, viscous product, well soluble in ordinary organic solvents. The structure and composition of this compound was determined in terms of molecular mass, molecular refraction, FTIR, ${ }^{1} \mathrm{H},{ }^{13} \mathrm{C}$ and ${ }^{29} \mathrm{Si} \mathrm{NMR}$ spectra data.

In the FTIR spectra of compound I, the carbon-fluorine bond stretching appears in the infrared spectrum between $1000 \mathrm{~cm}^{-1}$ and $1360 \mathrm{~cm}^{-1} .{ }^{11}$ From the

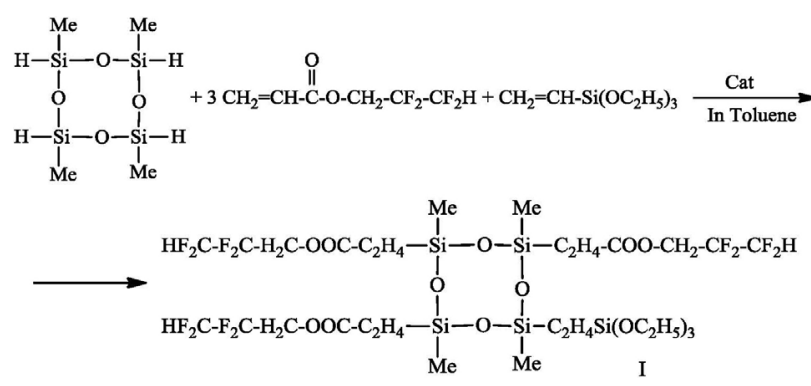

Scheme 1: Hydrosilylation reaction of $\mathrm{D}_{4}{ }^{\mathrm{H}}$ with 2.2.3.3-tetrafluoropropyl acrylate and vinyltriethoxysilane

literature, it is known that monofluorinated compounds have a strong band between $1000 \mathrm{~cm}^{-1}$ and $1110 \mathrm{~cm}^{-1}$; with more than one fluorine atoms, the band splits into two bands, one for the symmetric mode and the other for the asymmetric one. ${ }^{17}$ Carbon-fluorine bonds are so strong that they can replace the existing carbon-hydrogen bonds. ${ }^{18,19}$ In our case, in the spectra, one can observe absorption bands at $1128 \mathrm{~cm}^{-1}$ and $958 \mathrm{~cm}^{-1}$, characteristic of the valence and fan-shaped oscillation of $\mathrm{CF}_{2}$ groups, respectively. The absorption band in a range of $2160-2170 \mathrm{~cm}^{-1}$ characteristic of the $\equiv \mathrm{Si}-\mathrm{H}$ bonds disappears.

For compounds I, we also obtained ${ }^{29} \mathrm{Si}$ NMR spectra. One can observe the chemical shifts at $\delta=-18.6$ - $-20.4 \mathrm{mg} / \mathrm{L}$ and-26.9- $-27.7 \mathrm{mg} / \mathrm{L}$, characteristic of the RR'SiO (D) unit in a cyclic fragment, signals at $\delta=$ -44.9 to $-55.7 \mathrm{mg} / \mathrm{L}$ attributed to the isotactic and atactic resonance reorganization of $\mathrm{D}^{\mathrm{OR}}$ fragments and a signal at $\delta=-65 \mathrm{mg} / \mathrm{L}$, characteristic of the silica T-rings in the triethoxysilylated groups - in agreement with the literature data. ${ }^{14,15}$

\subsection{Ring-opening co-polymerization reaction of $D_{4}{ }^{R, R^{\prime}}$ with hexamethyldisiloxane}

We studied co-polymerization reactions of compounds I $\left(\mathrm{D}_{4}{ }^{\mathrm{R}, \mathrm{R}^{\prime}}\right)$ with hexamethyldisiloxane as the terminating agent at a 5:1 ratio of the initial compounds, in the presence of nucleophilic powdery anhydrous potassium hydroxide at a temperature of $90-110{ }^{\circ} \mathrm{C}$.

Co-polymerization reactions of compounds I were carried out in a 70-80\% solution of dry toluene in the presence of $0.01 \%$ of mass fractions of potassium hydroxide. Changes in the viscosity during the progressing reaction were followed. The reaction proceeds according to Scheme 2.

Therefore, the obtained polymers were precipitated and washed with pentane and dried in a vacuum up to a constant mass. These polymers are viscous, transparent liquids, well soluble in organic solvents including toluene and chloroform, with $\eta_{\mathrm{sp}} \approx 0.19$. The structures and compositions of the polymers were determined by means of FTIR, ${ }^{1} \mathrm{H},{ }^{13} \mathrm{C}$ and ${ }^{29} \mathrm{Si}$ NMR spectra.

In the FTIR spectra of polymers II, one can observe that the carbon-fluoride bonds are so strong that they 


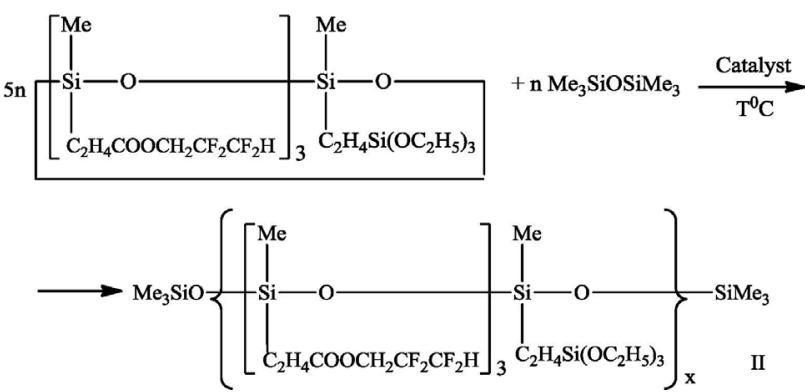

Scheme 2: Polymerization reaction of compound I results at $110^{\circ} \mathrm{C}$ as II

overlap all carbon-hydrogen bonds. ${ }^{17}$ In our case, in the spectrum, one can observe absorption bands in the 1128 and $958 \mathrm{~cm}^{-1}$ regions, characteristics of the valence and fan-shaped oscillations, respectively.

From gel-permeation chromatography investigations, we obtained the values of the number and weight average molecular mass, presented above in Section 2.4.

The DSC results show a single glass-transition temperature cantered around $-80.4{ }^{\circ} \mathrm{C}$ and no crystallization was observed. Hence, the use of these polymers for solid electrolyte membranes is possible.

\subsection{Preparation of solid polymer electrolyte mem- branes}

Sol-gel reactions were performed for polymer II. Along with the 2.2.3.3-tetrafluoropropyl propionate groups, we had ethyl triethoxysilyl groups in the side chains that made sol-gel reactions possible. To the solution of polymer II in tetrahydrofuran, we added certain amounts $(5,10,15$ and $20 \%$ of mass fractions) of lithium triflate or lithium bis(trifluoromethanesulfonyl)-imide. After one hour of stirring, 1-2 drops of HCI solution in ethanol were added and the stirring continued for 1-2 h, maintaining an inert atmosphere throughout the night. Afterwards, at various tempera-
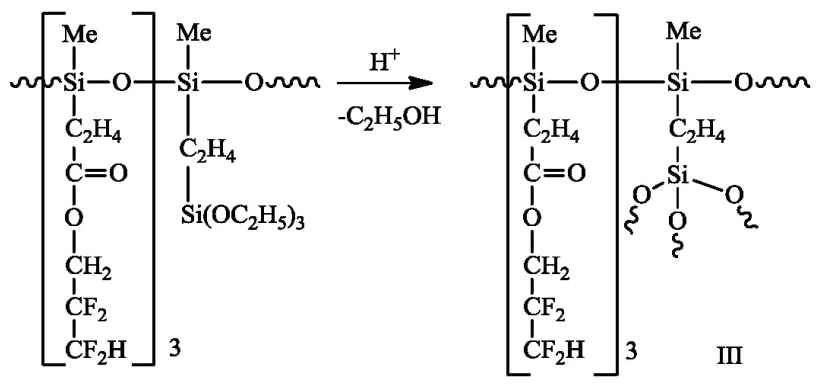

Scheme 3: Sol-gel reaction of polymer II

tures in the interval of $30-70{ }^{\circ} \mathrm{C}$ under a vacuum, we obtained solid polymer electrolyte membranes. Sol-gel reactions of polymer II proceed according to Scheme 3 .

We obtained polymer electrolyte membranes III based on lithium triflate: III (1) with $5 \%$; III (2) with $10 \%$, III (3) with $15 \%$ and III (4) with $20 \%$. On the basis of lithium bis(trifluoromethanesulfonyl)imide, we obtained: III (5) with $5 \%$, III (6) with $10 \%$, III (7) with $15 \%$ and III (8) with $20 \%$.

The DSC diagram for a membrane shows the glass-transition temperature $T_{\mathrm{g}}$, the region centred around $-83{ }^{\circ} \mathrm{C}$ and the softening temperature $T_{\text {soft }}$ centred around $+42{ }^{\circ} \mathrm{C}$.

Given the membrane applications, the thermogravimetric analysis (TGA) was carried out in air. The samples exhibit a gradual weight loss of about $8-12 \%$, which is due to the removal of the residual solvent and moisture from the electrolyte sample in the temperature range of $90-110{ }^{\circ} \mathrm{C}$. Further $5-\%$ mass losses can be observed between $200{ }^{\circ} \mathrm{C}$ and $250{ }^{\circ} \mathrm{C}$. Above $250{ }^{\circ} \mathrm{C}$, degradation processes occur, continuing up to $500{ }^{\circ} \mathrm{C}$.

For membrane III (3) (15\% of $\mathrm{CF}_{3} \mathrm{SO}_{3} \mathrm{Li}$ salt), we found a fairly smooth and uniform surface morphology on SEM micrographs. This confirmed a completely amorphous nature of the PE membrane and a full dissolution of the lithium salt, which also coincided with

Table 1: Specific volumetric electric resistance $\left(\rho_{\mathrm{v}}\right)$ and conductivity $\left(\sigma_{\mathrm{v}}\right)$ of polymer electrolytes based on membranes III at $25{ }^{\circ} \mathrm{C}$ and $90{ }^{\circ} \mathrm{C}$

\begin{tabular}{|c|c|c|c|c|c|}
\hline$\#$ & Membrane III & Salt, $w / \%$ & $\begin{array}{c}\rho_{\mathrm{v}} \text { at } 25^{\circ} \mathrm{C} \\
\Omega \times \mathrm{cm}\end{array}$ & $\begin{array}{l}\sigma_{\mathrm{v}} \text { at } 25{ }^{\circ} \mathrm{C}, \\
\text { Siemens } / \mathrm{cm}\end{array}$ & $\begin{array}{l}\sigma_{\mathrm{v}} \text { at } 90{ }^{\circ} \mathrm{C}, \\
\text { Siemens } / \mathrm{cm}\end{array}$ \\
\hline 1 & III (1) & $\mathrm{CF}_{3} \mathrm{SO}_{3} \mathrm{Li}, 5 \%$ & $5.3 \times 10^{9}$ & $1.9 \times 10^{-10}$ & $6.5 \times 10^{-8}$ \\
\hline 2 & III (2) & $\mathrm{CF}_{3} \mathrm{SO}_{3} \mathrm{Li}, 10 \%$ & $3.3 \times 10^{7}$ & $3.0 \times 10^{-6}$ & $9.6 \times 10^{-6}$ \\
\hline 3 & III (3) & $\mathrm{CF}_{3} \mathrm{SO}_{3} \mathrm{Li}, 15 \%$ & $1.8 \times 10^{6}$ & $5.5 \times 10^{-7}$ & $8.9 \times 10^{-5}$ \\
\hline 4 & III (4) & $\mathrm{CF}_{3} \mathrm{SO}_{3} \mathrm{Li}, 20 \%$ & $7.5 \times 10^{5}$ & $1.3 \times 10^{-7}$ & $9.2 \times 10^{-5}$ \\
\hline 5 & III (5) & $\left(\mathrm{CF}_{3} \mathrm{SO}_{2}\right)_{2} \mathrm{NLi}, 5 \%$ & $4.8 \times 10^{9}$ & $2.1 \times 10^{-10}$ & $3.8 \times 10^{-8}$ \\
\hline 6 & III (6) & $\left(\mathrm{CF}_{3} \mathrm{SO}_{2}\right)_{2} \mathrm{NLi}, 10 \%$ & $3.4 \times 10^{5}$ & $2.9 \times 10^{-6}$ & $7.7 \times 10^{-5}$ \\
\hline 7 & III (7) & $\left(\mathrm{CF}_{3} \mathrm{SO}_{2}\right)_{2} \mathrm{NLi}, 15 \%$ & $7.0 \times 10^{6}$ & $1.4 \times 10^{-7}$ & $1.1 \times 10^{-6}$ \\
\hline 8 & III (8) & $\left(\mathrm{CF}_{3} \mathrm{SO}_{2}\right)_{2} \mathrm{NLi}, 20 \%$ & $8.2 \times 10^{5}$ & $1.2 \times 10^{-7}$ & $8.5 \times 10^{-7}$ \\
\hline 9 & III (9) & $\left(\mathrm{CF}_{3} \mathrm{SO}_{3} \mathrm{Li}\right)(20)+\mathrm{Al}_{2} \mathrm{O}_{3}(2.5 \%)$ & $1.7 \times 10^{5}$ & $6.2 \times 10^{-6}$ & $7.5 \times 10^{-5}$ \\
\hline 10 & III (10) & $\left(\mathrm{CF}_{3} \mathrm{SO}_{3} \mathrm{Li}\right)(20)+\mathrm{Al}_{2} \mathrm{O}_{3}(5 \%)$ & $2.0 \times 10^{4}$ & $1.1 \times 10^{-5}$ & $1.8 \times 10^{-4}$ \\
\hline 11 & III (11) & $\left(\mathrm{CF}_{3} \mathrm{SO}_{3} \mathrm{Li}\right)(20)+\mathrm{Al}_{2} \mathrm{O}_{3}(7.5 \%)$ & $1.3 \times 10^{5}$ & $7.8 \times 10^{-6}$ & $4.5 \times 10^{-5}$ \\
\hline 12 & III (12) & $\left(\mathrm{CF}_{3} \mathrm{SO}_{3}\right) \mathrm{NLi},(20 \%)+\mathrm{Al}_{2} \mathrm{O}_{3}(10 \%)$ & $2.3 \times 10^{5}$ & $4.0 \times 10^{-6}$ & $1.1 \times 10^{-4}$ \\
\hline 13 & III (13) & $\left(\mathrm{CF}_{3} \mathrm{SO}_{2}\right)_{2} \mathrm{NLi},(10 \%)+\mathrm{Al}_{2} \mathrm{O}_{3}(2.5 \%)$ & $3.3 \times 10^{4}$ & $3,2 \times 10^{-5}$ & $2.6 \times 10^{-4}$ \\
\hline 14 & III (14) & $\left(\mathrm{CF}_{3} \mathrm{SO}_{2}\right)_{2} \mathrm{NLi},(10 \%)+\mathrm{Al}_{2} \mathrm{O}_{3}(5 \%)$ & $5.1 \times 10^{3}$ & $2.0 \times 10^{-4}$ & $3.1 \times 10^{-3}$ \\
\hline 15 & III (15) & $\left(\mathrm{CF}_{3} \mathrm{SO}_{2}\right)_{2} \mathrm{NLi},(10 \%)+\mathrm{Al}_{2} \mathrm{O}_{3}(7.5 \%)$ & $3.3 \times 10^{4}$ & $3,2 \times 10^{-5}$ & $6.6 \times 10^{-4}$ \\
\hline 16 & III (16) & $\left(\mathrm{CF}_{3} \mathrm{SO}_{2}\right)_{2} \mathrm{NLi},(10 \%)+\mathrm{Al}_{2} \mathrm{O}_{3}(10 \%)$ & $2.8 \times 10^{5}$ & $3.6 \times 10^{-6}$ & $2.7 \times 10^{-5}$ \\
\hline
\end{tabular}




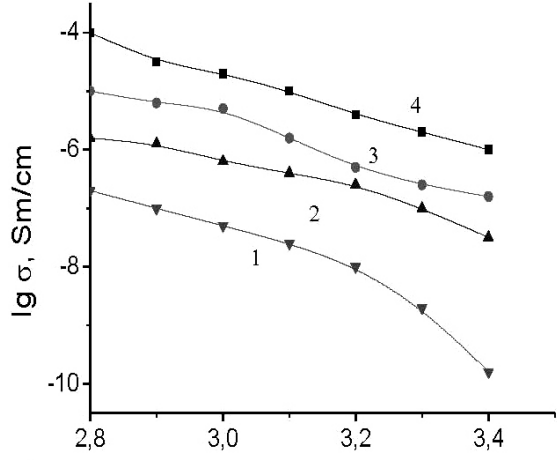

a)

$1000 / \mathrm{K}$

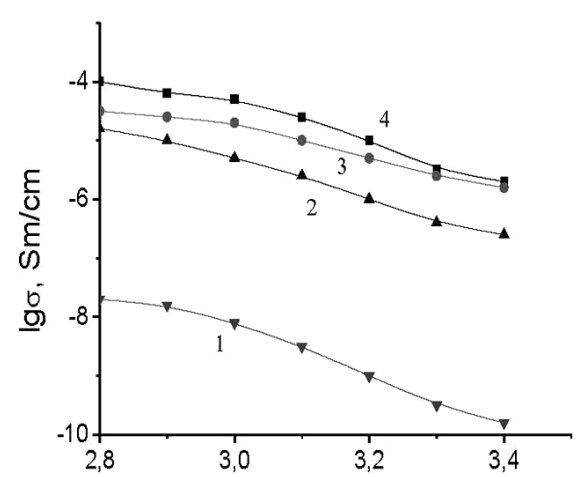

b)

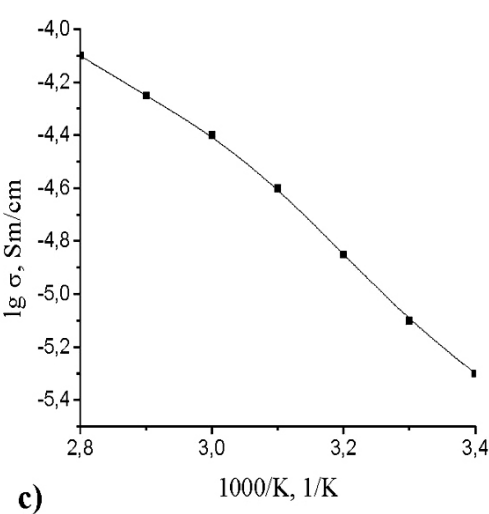

c)

Figure 1: Temperature dependence of the conductivity in Arrhenius coordinates of the solid polymer electrolytes based on: a) III-type membranes with salt $\mathrm{CF}_{3} \mathrm{SO}_{3} \mathrm{Li}$ at concentrations (w/\%)of $5 \%$ (1), $10 \%$ (2), $15 \%$ (4) and 20\% (3); b) III-type membranes with salt $\left(\mathrm{CF}_{3} \mathrm{SO}_{2}\right)_{2} \mathrm{NLi}$ at concentrations $((w / \%))$ of $5(1), 10 \%(3), 15 \%$ (2) and $20 \%$ (4); c) III-type membrane with a blend of salt $\mathrm{CF}_{3} \mathrm{SO}_{3} \mathrm{Li}(10$ w/\%) and $\mathrm{Al}_{2} \mathrm{O}_{3}(10(w / \%))$

the XRD results. These images showed a good dispersion of the filler and small pores entrapping the ionic liquid. Well visible amorphous layers of lithium salts were reflected in a high ionic conductivity.

Table 1 below including membranes with different amounts of salt provides the values for the specific volumetric electric resistance and conductivity of the electrolytes at $25^{\circ} \mathrm{C}$ and $90{ }^{\circ} \mathrm{C}$.

As expected and seen in Table 1, the conductivity of the membranes essentially depends on the polymer matrix, the salt type and its concentration. Thus, first, the extreme dependence of the electrical conductivity of the membranes on the salt concentration attracts attention the maximum conductivity is observed near the concentration of $10 \%$. This dependence is explained with an increase in the probability of the formation of ion pairs at elevated salt concentrations. In an electrical flow, these pairs move as one, but since the effective mass and mobility of these pairs are greater than for individual electrons, the total electric current in the membranes with electron pairs is weaker than that in the membranes whose current is carried by individual electrons. ${ }^{20-22} \mathrm{We}$ investigated the temperature dependences of the

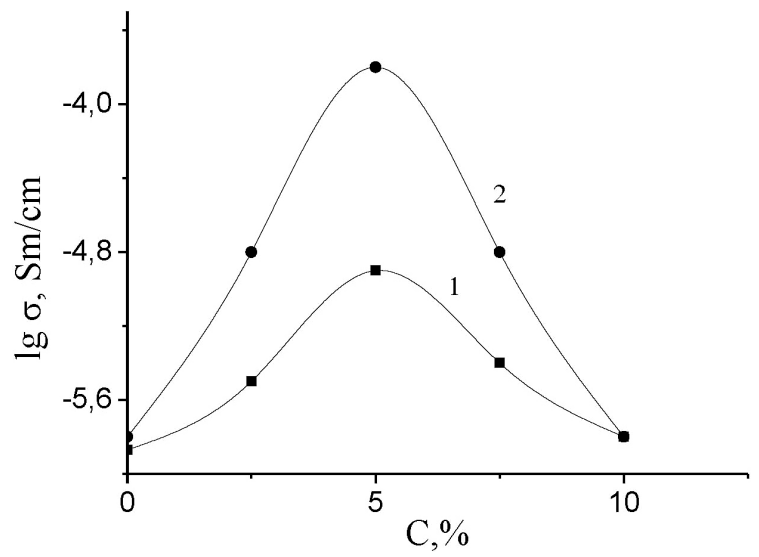

Figure 2: Dependence of the conductivity of membranes of type III on the concentration of $\mathrm{Al}_{2} \mathrm{O}_{3}$ containing 20 w/\% of the $\mathrm{CF}_{3} \mathrm{SO}_{3}$ salt (1) and $10 \mathrm{w} / \%$ of the $\left(\mathrm{CF}_{3} \mathrm{SO}_{2}\right)_{2} \mathrm{NLi}$ salt (2) at room temperature properties of the solid polymer electrolytes in a range of 25-90 ${ }^{\circ} \mathrm{C}$. The results pertaining to the membranes listed are presented in Arrhenius coordinates in Figure 1.

We compared the conductivities with and without corundum. In Table 1 and Figure 2, we show that, in general, electric conductivity of membranes increases with an increasing oxide concentration in the interval of $0-10$ wt.\%. However, with a further increase in the oxide concentration the membrane conductivity decreases. A possible explanation for this is as follows: at lower concentrations, the corundum particles promote a homogeneous distribution of the salt particles in the matrix. However, at higher concentrations the same particles decrease the salt ion mobility because of the increased interactions between the salt ions and oxide particles and, correspondingly, the conductivity of the membranes decreases.

Figure 3 presents voltammograms, that is, the curves of dependence of electric current on the voltage applied. The main feature of these curves is the increasing of the current with the following deceleration in the current growth. The dependence of the length of the linear part

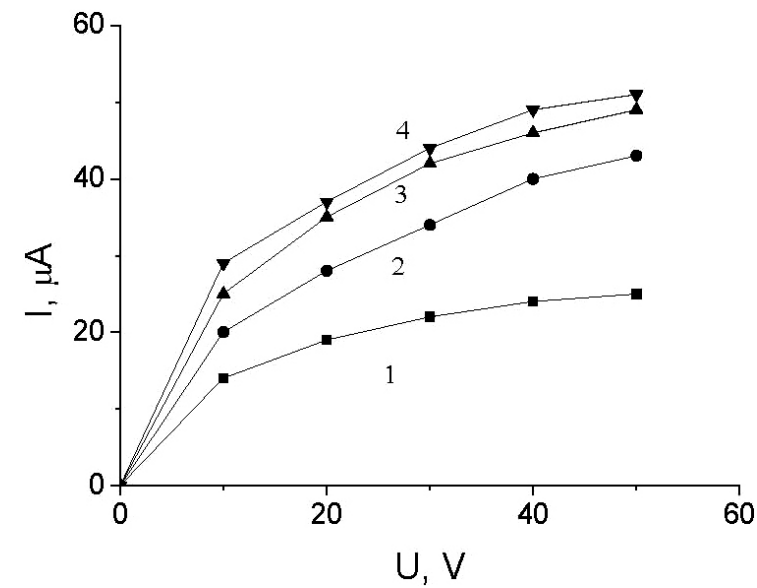

Figure 3: Voltammograms for membranes of type III containing 5 (1), 15 (2), 20 (3) and $10 w / \%(4)$ of salt I 
of the curve depends essentially on the interactions discussed above.

\section{CONCLUSIONS}

With a hydrosilylation reaction of tetrahydrotetramethylcyclotetrasiloxane with 2.2.3.3-tetrafluoropropyl acrylate and vinyltriethoxysilane at a 1:3:1 ratio of the initial compounds, in the presence of platinum catalysts, the corresponding adduct $\mathrm{D}_{4}{ }^{\mathrm{R}, \mathrm{R}}$ ' was obtained.

Via a copolymerization reaction of $\mathrm{D}_{4}{ }^{\mathrm{R}, \mathrm{R}^{\prime}}$ with terminating agent hexamethyldisiloxane at a 5:1 ratio of the initial compounds, in the presence of a catalyst, comb-type polymers were obtained. With a sol-gel reaction of the obtained polymer doped with lithium trifluoromethanesulfonate (triflate) and lithium bis(trifluoromethanesulfonyl)imide, solid polymer electrolyte membranes were obtained.

The conductivity of the membranes in the range of $25-90{ }^{\circ} \mathrm{C}$ can be described with an equation close to the VTF type. The membranes containing $10 \mathrm{w} / \%$ of salt $\mathrm{CF}_{3} \mathrm{SO}_{3} \mathrm{~L}$ are characterized with a higher conductivity in this range of temperatures, which is three orders higher than that of the analogue membranes containing $5 \mathrm{w} / \%$ of the same salt. The conductivity of electrolytes containing $15 \mathrm{w} / \%$ and $20 \mathrm{w} / \%$ of this salt is lower than for the analogue ones with $10 \mathrm{w} / \%$ of salt because of the formation of ion pairs with a mobility lower than that of mono-ions. The characteristic of the voltammograms of these electrolytes corresponds to the value of conductivity of the electrolytes - the higher the conductivity, the higher is the specific electric current in these materials.

\section{Acknowledgment}

The financial support of the Georgian National Science Foundation, Science and Technology Centre in Ukraine, Grant - STCU-2016-16 (6301), is gratefully acknowledged.

\section{REFERENCES}

${ }^{1}$ J. Muldoon, C. B. Bucur, N. Boaretto, T. Gregory V. Di Noto, Polymers: opening doors to future batteries, Polymer Reviews, 55 (2015), 208-246, doi:10.1080/15583724.2015.1011966

${ }^{2}$ J. G. Kim, B. Son, S. Mukherjee, N. Schuppert, A. Bates, O. Kwon, M. J. Choi, H. Y. Chung, S. Park, A review of lithium and non-lithium based solid state batteries, J. Power Sources, 282 (2015), 299-322, doi:10.1016/j.jpowsour.2015.02.054

${ }^{3}$ C. Sun, J. Liu, Yu. Gong, D. P. Wilkinson, J. Zhang, Recent advances in all-solid-state rechargeable lithium batteries, Nano Energy, 33 (2017), 363-386, doi:doi:10.1016/j.nanoen.2017.01.028

${ }^{4}$ J. B. Goodenough, K-S. Park, The li-ion rechargeable battery: a perspective, J. Am. Chem. Soc., 135 (2013) 4, 1167-1176, doi:10.1021/ja3091438
${ }^{5}$ M. Grünebaum, M. H. Hiller, S. Jankowsky, S. Jeschke, B. Pohl, T. Schürmann, Synthesis and electrochemistry of polymer based electrolytes for lithium batteries, Prog. Solid State Chem., 42 (2014) 4, 85-105, doi:10.1016/j.progsolidstchem.2014.04.004

${ }^{6}$ L. Yue, J. Ma, J. Zhang, J. Zhao, Sh. Dong, G. Cui, L. Chen, All solid-state polymer electrolytes for high-performance lithium ion batteries, Energy Storage Mater., 5 (2016), 139-164, doi:10.1016/ j.ensm.2016.07.003

${ }^{7}$ D.-G. Kim, J. Shim, J. H. Lee, S.-J. Kwon, J.-H. Baik, J.-C. Lee, Preparation of solid-state composite electrolytes based on organic/inorganic hybrid star-shaped polymer and PEG-functionalized POSS for all-solid-state lithium battery applications, Polymer, 54 (2013) 21, 5812-5820, doi:10.1016/j.polymer.2013.08.049

${ }^{8}$ H. B. Youcef, O. Garcia-Calvo, N. Lago, S. Devaraj, M. Armand, cross-linked solid polymer electrolyte for all-solid-state rechargeable lithium batteries, Electrochim. Acta, 220 (2016), 587-594, doi:10.1016/j.electacta.2016.10.122

${ }^{9}$ T. M. Liu, D. Saikia, S.-Y. Ho, M.-C. Chen, H.-M. Kao, High ion-conducting solid polymer electrolytes based on blending hybrids derived from monoamine and diamine polyethers for lithium solid-state batteries, RSC Adv., 7 (2017), 20373-20383, doi:10.1039/C7RA01542A

${ }^{10}$ N. Boaretto, C. Joost, M. Seyfried, K. Vezzù, V. Di Noto, Conductivity and properties of polysiloxane-polyether cluster-LiTFSI networks as hybrid polymer electrolytes, J. Power Sources, 325 (2016), 427-437, doi:10.1016/j.jpowsour.2016.06.034

${ }^{11}$ T. Tatrishvili, G. Titvinidze, N. Pirckheliani, J. Aneli, G. Zaikov, O. Mukbaniani, Hydrosilylation reactions of polymethylhydrosiloxane with acrylates and methacrylates and solid polymer electrolyte membranes on their basis, Oxid. Comm., 2 (2015), 776-788

${ }^{12}$ O. Mukbaniani, W. Brostow, J. Aneli, T. Tatrishvili, E. Markarashvili, M. Chigvinadze, I. Esartia, Synthesis and ionic conductivity of siloxane based polymer electrolytes with pendant propyl acetoacetate groups, Pure \& Appl. Chem., 90 (2018) 6, 989-999, doi:10.1515/pac-2017-0805

${ }^{13}$ T. Iwahara, M. Kusakabe, M. Chiba, K. Yonezawa, Synthesis of novel organic oligomers containing Si-H bonds, J. Polym. Sci. A, 31 (1993) 10, 2617-2631, doi:10.1002/pola.1993.080311023

${ }^{14}$ C. Lin, H. Kao, R. Wu, P. Kuo, multinuclear solid-state NMR, DSC, and conductivity studies of solid polymer electrolytes based on polyurethane/poly(dimethylsiloxane) segmented copolymers, Macromolecules, 35 (2002), 3083-3096, doi:10.1021/ma012012q

${ }^{15}$ J. M. Ziman, Principles of the theory of solids, Cambridge University Press, 1964, 221

${ }^{16}$ O. Mukbaniani, T. Tatrishvili, E. Markarashvili, E. Esartia, Hydrosilylation reaction of tetramethylcyclotetrasiloxane with allyl butyrate and vinyltriethoxysilane, Georgian Chem. J, 2 (2011) 11, 1535

${ }^{17}$ https://en.wikipedia.org/wiki/Infrared, 10.01.2020

${ }^{18} \mathrm{G}$. Socrates, Infrared and Raman characteristic group frequencies: tables and charts, John Wiley and Sons, 2001, 198

${ }^{19}$ B. H. Stuart, Infrared Spectroscopy, Fundamentals and Applications, John Wiley and Sons, 2004, 82

${ }^{20}$ N. A. Rossi, R. West, Silicon-containing liquid polymer electrolytes for application in lithium ion batteries, Polym. Int., 58 (2009), 267-272, doi: 10.1002/pi.2523

${ }^{21}$ J. F. Snyder, M. A. Ratner, D. F. Shriver, Ion conductivity of comb polysiloxane polyelectrolytes containing oligoether and perfluoroether sidechains, J. Electrochem. Soc., 150 (2003) 8, A1090-A1094, doi: $10.1149 / 1.1589759$

${ }^{22}$ J. F. Snyder, J. C. Hutchison, M. A. Ratner, D. F. Shriver, Synthesis of comb polysiloxane polyelectrolytes containing oligoether and perfluoroether side chains, Chem. Mater., 15 (2003) 22, 4223-4230, doi: $10.1021 / \mathrm{cm} 0217396$ 